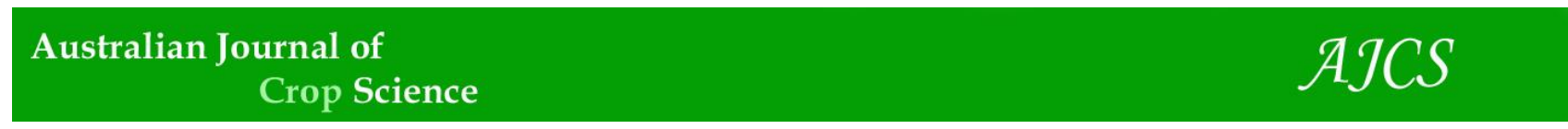

AJCS 11(10):1315-1319 (2017)

ISSN:1835-2707

doi: 10.21475/ajcs.17.11.10.pne603

\title{
Artificial vernalization in strawberry plants: phyllochron, production and quality
}

\author{
Maria Inês Diel ${ }^{1 *}$, Marcos Vinícius Marques Pinheiro ${ }^{2}$, Carine Cocco $^{3}$, Leonardo Antonio Thiesen ${ }^{2}$, \\ Bruna Stringari Altíssimo ${ }^{2}$, Daniele Cristina Fontana ${ }^{2}$, Bráulio Otomar Caron ${ }^{2}$, Valéria Testa ${ }^{2}$, Denise \\ Schmidt $^{2}$
}

${ }^{1}$ Agronomy Department, Federal University of Santa Maria, Santa Maria-RS, Brazil

${ }^{2}$ Federal University of Santa Maria - Campus Frederico Westphalen- 7th of September Line, s / n BR 386 Km 40, Frederico Westphalen - RS CEP: 98400-000, Brazil

${ }^{3}$ University of Caxias do Sul, Francisco Getúlio Vargas Street, 1130. CEP 95070-560 - Caxias do Sul / RS, Brazil

*Corresponding author: mariaines.diel@hotmail.com

\begin{abstract}
To obtain the best productive performances strawberry plants require an accumulation of cold hours which varies by cultivar; this project evaluated phyllochron, the quality and fruit production from vernalized and non-vernalized seedlings of the strawberry cultivars Albion and Camarosa. The treatments consisted of seedling vernalized before planting for 200 cold hours in a cold chamber with temperatures $4.0{ }^{\circ} \mathrm{C}$. Seedlings in the control treatments were not vernalized and were transplanted directly after arrival. Phyllochron was evaluated (estimated by the inverse of the angular coefficient of the linear regression between the number of leaves in the main crown and the sum of thermal time accumulated for each transplanted seedling), in addition to production parameters (number of commercial fruits, number of non-commercial fruits, production of commercial and non-commercial fruits); and fruit quality (titratable acidity, total soluble solids and ratio titratable acidity/total soluble solids). The exposure of strawberry seedlings to vernalization treatments significantly affected productivity but did not affect leaf emission rates or quality of fruits, although these factors were different among cultivars. Camarosa showed greater leaf emission rates and higher productivity per plant and lower titratable acidity than Albion which may be related to genotypic acclimatization. Seedling vernalization is recommended because it results in greater fruit production. The cultivar with higher fruit production is Camarosa.
\end{abstract}

Keywords: Fragaria x ananassa, seedlings, cultivars, hours of cold.

Abbreviations: ${ }^{\circ} \mathrm{C} \_$degrees Celsius, Std_daily thermal sum, Tb_base temperature, Tave_average temperature, Tmax_maximum temperature, Tmin_minimum temperature, g_grams, $\mathrm{NaOH} \_$sodium hydroxide, $\mathrm{NCF}$ nnumber of commercial fruits, $\mathrm{NNCF}$ _number of non-commercial fruit, $\mathrm{PNCF} \_$production of non-commercial fruit, $\mathrm{PCF} \_$production of commercial fruits, $\mathrm{Kg}$ _kilogram, $\mathrm{m}_{-}$meter, $\mu$ m_micrometer.

\section{Introduction}

Strawberries are cultivated worldwide and are known for being an attractive fruit, with a pleasant smell and taste, and are a good source of potassium, vitamins $\mathrm{C}$ and $\mathrm{E}$, folic acid, carotenoids, and phenolic compounds which confer antioxidant properties (Yang et al., 2016). It is an economically viable fruit which is becoming more popular in family-farm systems, and can add considerable value to small properties. Strawberries are distributed throughout several regions of Brazil, especially in the states of Minas Gerais, Rio Grande do Sul, Paraná, Santa Catarina, São Paulo, Espírito Santo, Distrito Federal, Bahia, and Ceará (Anuário Brasileiro de Fruticultura, 2015).

Most Brazilian strawberry farming operations use imported seedlings from Chilean and Argentine nurseries (Antunes and Peres 2013). In places of high altitudes, it has been found that temperate climates can improve the quality of seedlings due to a higher accumulation of reserves in the crown and roots of plants grown in this climate (Ruan et al., 2009).

In regions with mild climates, the ideal date for the planting of strawberries is generally considered to occur in the months of February to April because these plants bear fruit in times of shortage. The planting season of seedlings usually occurs between May and July because planting is dependent on the production schedule of international producers and the time required for seedlings to pass through import markets and be delivered to producers. The system, coupled with common delays in delivery, often results in the late planting of strawberry seedlings. The development of strawberry cultures is widely influenced by temperature and photoperiod, these factors impact the production and quality of produced fruits. Seedlings produced in Chilean and Argentine nurseries must be kept longer in the field, in order to increase the beneficial effects of the cold on the accumulation of seedlings reserves and floral induction (Sonsteby et al., 2013). The seedlings produced in national nurseries usually have lower yields compared to imported seedlings due to an insufficient number of hours of cold (Wrege et al., 2007).

The production of domestic seedlings with specific physiological qualities could allow them to be planted early and result in an earlier production of fruits (Cocco et al., 2011). A strategy to increase the floral differentiation and increase fruit production may be seen in the artificial vernalization of seedlings. This practice provides artificial 
conditions of temperature, with an aim to stimulate the differentiation of flower (Costa et al., 2014).

In addition, imported strawberry seedlings are expensive and result in higher total costs of crop production when compared to the national seedlings. National seedlings may see production costs at half of the international cost. In order to evaluate the production of domestic seedlings and improve the productivity of crops, this project evaluated phyllochron, quality and fruit production from vernalized and nonvernalized seedlings in the strawberry cultivars, Albion and Camarosa.

\section{Results and discussion}

\section{Temperatures in the growing environment}

The maximum and minimum temperature recorded inside the tunnels during the experiment between May and December was 46.6 and $-0.7{ }^{\circ} \mathrm{C}$, respectively (Fig. 1). It is known that strawberries can be positively and negatively influenced by both temperature and photoperiod (Sonsteby et al., 2013), and these factors are responsible for the induction of flowering (Sonsteby and Heide 2007) and responsible for leaf emission rates on the main crown (Mendonça et al., 2012).

The temperatures considered optimal for floral initiation under short-day conditions are between 15 and $18^{\circ} \mathrm{C}$, being that above $25^{\circ} \mathrm{C}$ and below $10^{\circ} \mathrm{C}$ floral induction decreases daily and nightly temperatures are also important and vary according to the cultivar (Verheul et al., 2007). This is one factor that may affect the amount of fruit produced.

A certain amount of hours of cold is important for the occurrence of floral induction (Verheul et al., 2007). According to Duarte Filho et al., (1999), if a seedling's cold requirement is not met in the nursery, it can be performed at later point in cold chamber, or after the planting in the definitive local (Verdial et al., 2007). An excessive accumulation of hours of cold during the dormancy period favors the development of stolons, leaves and crowns, while plants which did not have their needs for cold supplied may have reduced vegetative growth, delayed development, plant malformations, lower fruit masses and lower yields in the spring (Tanino and Wang 2008).

\section{Statistical analyses}

Among the variables analyzed, a significant difference was observed for the interactions between cultivar $\mathrm{x}$ treatment for total production of commercial fruits (Table 2). For the variables phyllochron, titratable acidity, number of commercial and non-commercial fruits and production of non-commercial fruits, a significance difference was observed for only factor of cultivar. For the variables total soluble solids and ratio of total soluble solids and titratable acidity (TSS/TA) the results were not significant (data not shown).

\section{Variable phyllochron}

For the variable phyllochron, it was observed that the Albion cultivar requires a higher accumulated thermal sum (STa), for the leaf emission in the main crown, while the Camarosa cultivar requires a lower Sta (Table 1). It was observed that the Camarosa cultivar emits leaves faster than Albion cultivar and this factor may contribute to higher photosynthetic rates and lead to better rates of development and fruit production. In other studies, the Albion cultivar also had a lower rate of leaf emission when compared to other cultivars, as observed by Mendonça et al., (2012), in a study in which this cultivar required higher accumulation of degree days to emit a leaf. Tazzo et al., (2015) found phyllochron values of $135.61^{\circ} \mathrm{C}$ day leaf ${ }^{-1}$ for the Albion cultivar, which is higher than what was seen for Camarosa. For the Albion cultivar, Costa et al., (2012) observed differences in phyllochron of vernalized and non-vernalized seedlings and the appearance of leaves on vernalized seedlings was $93.30^{\circ} \mathrm{C}$ day leaf ${ }^{-1}$, while for nonvernalized seedlings, the phyllochron was $117.80^{\circ} \mathrm{C}$ day leaf ${ }_{-1}$. The lower leaf emission rate in a plant resulted in higher phyllochron which means that plants likely needs a greater thermal sum for leaf emission (Rose et al., 2013). The cultivars in this study (Fig. 2) presented distinctly different performances for their development, as described by other authors (Mendonça et al., 2012; Rosa et al., 2013.).

For the Camarosa cultivar, which showed lower phyllochron, a greater amount of leaves (16 leaves) was observed as compared to Albion (10 leaves), from this morphological characteristic it can be inferred that Camarosa has a greater leaf area, unlike Albion which demonstrated a lesser rate for the transformation of photosynthetic energy and consequently a lesser accumulation of reserves (Tazzo et al., 2015), factors which can influence crop yields.

\section{Qualitative variables}

For variable titrable acidity, a lower value for Camarosa cultivar and higher for Albion was observed, giving a more acidic taste to the latter (Table 1). Differences between cultivars were also found by Samikanno et al., (2013), which verifies the higher titratable acidity values of the Albion cultivar. It was seen that the acidity of strawberry fruit is related to the cultivar, and that this factor affects more than growing conditions (Capocasa et al., 2008).

Comparing the cultivars: Camarosa, Candonga, Medina, Marina and Ventana in cultivation in soil in the southwestern Spain, Akhatou and Recamales (2013) found higher titratable acidity values to the cultivar Camarosa $(0.74 \%)$ which shows that there are significant differences among cultivars. The acidity is present in minor amounts in strawberry fruits but it is an important attribute of the flavor that, in combination with sugars, has an impact on the sensory quality of the fruit (Gunduz and Ozdemir 2014) and gives the fruits their characteristic flavor.

\section{Variables production}

For the variable number of commercial fruits (NCF), the Camarosa cultivar showed greater values when compared to Albion (Table 1). This was likely due to leaf emission rate, defined by the phyllochron, which was lower in the Camarosa cultivar and resulted in this cultivar being more efficient in the transformation of photosynthetic energy and the partitioning of photoassimilates (Tazzo et al., 2015) for the fruits.

The number of commercial fruits (NCF) of the Camarosa cultivar was higher to those reported by Radin et al., (2011), whom evaluated the number of fruits per plant of four cultivars. They found, on average, a value of 15.6 and 20.0 fruits for the Camarosa cultivar, this difference may be related to the local temperature differences and also to the genotype used.

The number of non-commercial fruits (NNCF) was also higher for the Camarosa cultivar (Table 1). Similar to the $\mathrm{NNCF}$, the production of non-commercial fruit (PNCF) was higher in Camarosa compared to Albion, as it had greater production (Table 1). This result may have been influenced by solar radiation during the harvest, as a decline in leaf area which limits energy partitioning by the lower photosynthetic 
Table 1. Values of phyllochron, titratable acidity (TA), number of commercial fruits (NCF), number of non-commercial fruits (NNCF) and production non-commercial fruit (PNCF) in strawberry cultivars Albion and Camarosa.

\begin{tabular}{|c|c|c|c|c|c|}
\hline Cultivar & $\begin{array}{l}\text { Phyllochron } \\
\left({ }^{\circ} \mathrm{C} \text { day leaf }{ }^{-1}\right)\end{array}$ & $\begin{array}{l}\text { TA } \\
\text { (\% of citric acid) }\end{array}$ & $\mathrm{NCF}$ & NNCF & $\begin{array}{l}\text { PNCF } \\
\text { (g/plant) } \\
\end{array}$ \\
\hline Albion & $287.50 \mathrm{a}$ & $1.10 \mathrm{a}$ & $14.50 \mathrm{~b}$ & $4.87 \mathrm{~b}$ & $35.56 \mathrm{~b}$ \\
\hline Camarosa & $182.80 \mathrm{~b}$ & $0.91 \mathrm{~b}$ & $64.87 \mathrm{a}$ & $21.37 \mathrm{a}$ & $147.77 \mathrm{a}$ \\
\hline $\mathrm{CV}(\%)$ & 34.07 & 11.80 & 29.40 & 38.42 & 40.20 \\
\hline
\end{tabular}

Means followed by the same letter in the column do not differ by Tukey test at level of $5 \%$ error probability (p <0.05).

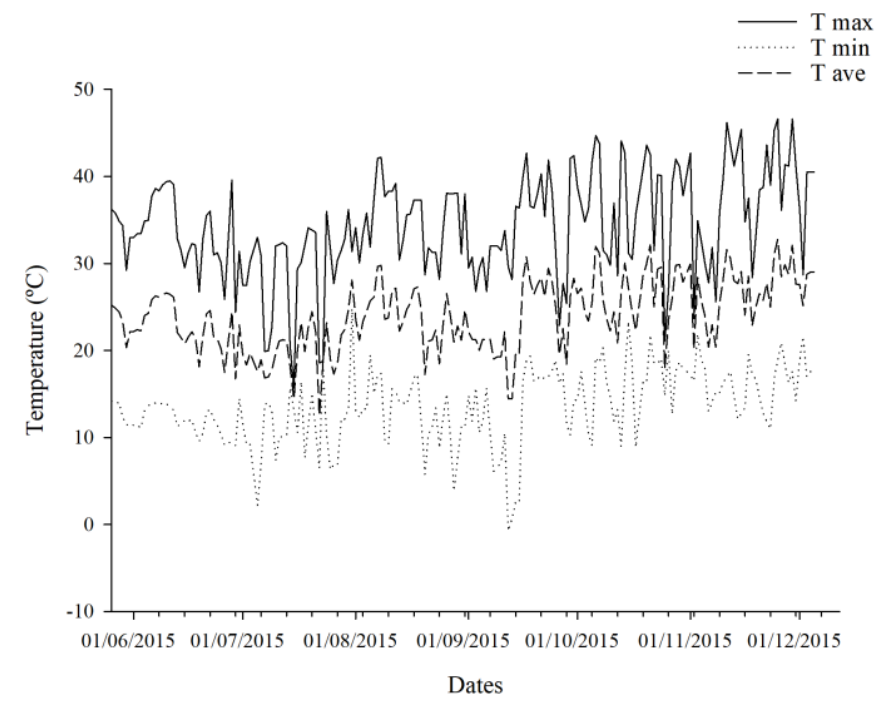

Fig 1. Average, maximum and minimum temperatures recorded inside the low tunnels in strawberry evaluation period.

Table 2. Production of commercial fruits of strawberry cultivars from vernalized and non-vernalized seedlings.

\begin{tabular}{lcr}
\hline \multirow{2}{*}{ Treatment } & Production of commercial fruits & (g/plant) \\
\cline { 2 - 3 } & Albion & Camarosa \\
\hline Vernalized & $207.10 \mathrm{aB}$ & $1.007 .50 \mathrm{aA}$ \\
Non vernalized & $196.91 \mathrm{aB}$ & $774.16 \mathrm{bA}$ \\
\hline CV $(\%)$ & 17.9 & \\
\hline Means followed by the same small letter in the column and capital letter in the line do not differ, at 5\% of significance.
\end{tabular}
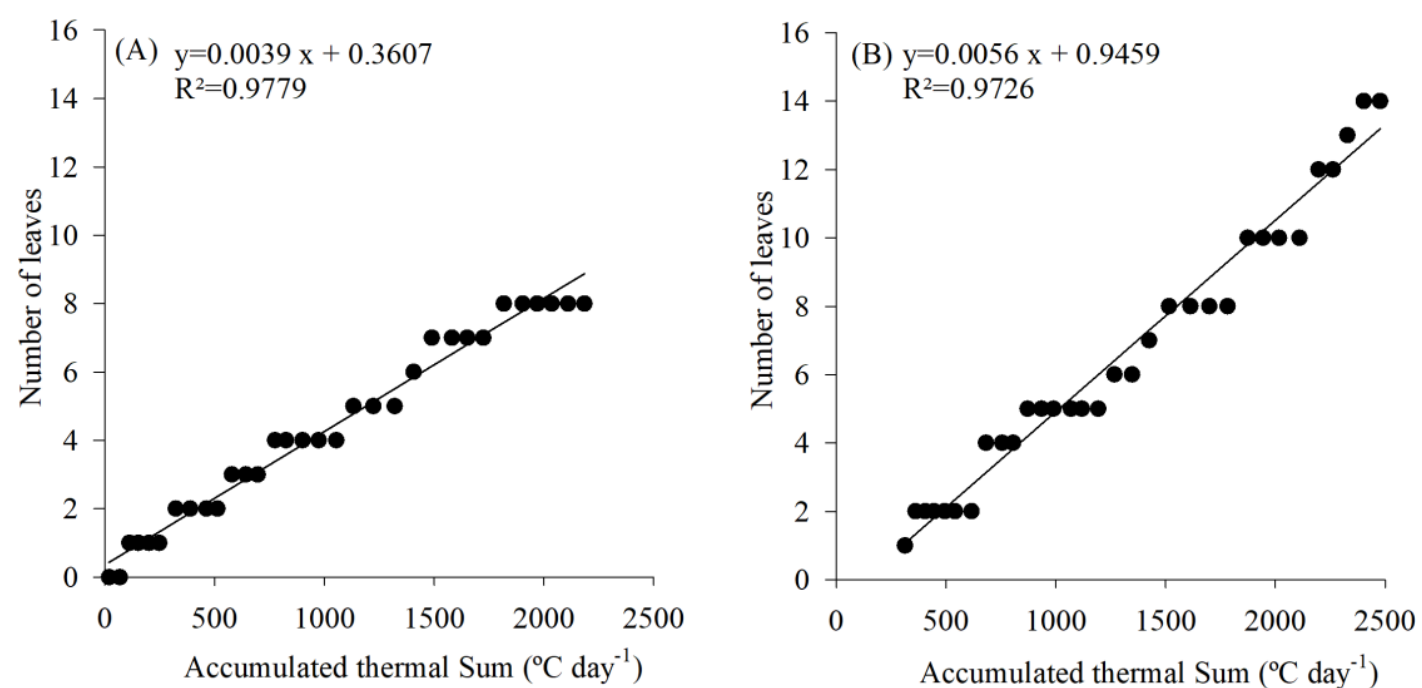

Fig 2. A linear regression was used to estimate the phyllochron of strawberry cultivars Albion (A) and Camarosa (B) for vernalized and non-vernalized seedlings.

surface occurs (Massa et al., 2015). The largest number of non-commercial fruit found for the Camarosa cultivar can be explained by higher branching of the inflorescence, which can result in a greater number of small fruit at the end of the cycle (Days et al.,2009). In the present study, pollination problems, as well as a nutritional deficiency of boron, may have caused a higher deformity of fruits. For the variable of production of commercial fruits (PCF), which is the fruit 
yield in grams/plant, the Camarosa cultivar showed the highest yield when submitted to the cold treatments, moreover it showed the best productions for Albion (Table 2). Temperature affects vegetative development, production and fruit quality, and is the main limiting factor of strawberry crops (Serçe and Hancock 2005), and hours of cold are important for the occurrence of floral induction (Verheul et al., 2007). A lack of cold hours can cause developmental delays, poor formation, lower fruit mass and lower production yield in the spring (Tanino and Wang 2008).

The biggest difference observed for the variable PCF was observed for the cultivar factor, in which the Camarosa was greater than Albion; this advantage may be related to the high amount of leaves observed in Camarosa leading to a greater utilization of photosynthetic solar radiation and higher efficiency for the conversion of photoassimilates (Tazzo et al., 2015). In the present study, the Camarosa cultivar had a higher productivity when compared to that found by Pereira et al., (2013), when compared it with Aromas, Festival and Oso Grande in different growing seasons in southern Minas Gerais. These results can be explained by the interaction between genotype and environment, in which certain cultivars have better acclimatization and thus express more clearly its production capacity.

Carvalho et al., (2013) evaluated the productive performance of different cultivars in the city of Pelotas-RS in which the Camarosa cultivar presented a production rate of $729.17 \mathrm{~g} /$ plant. Similar results were observed in the present work for Camarosa cultivar in the treatment without vernalization. Other studies have also reported higher productivity for the Camarosa cultivar (Oliveira et al., 2009; Cocco et al., 2011), which demonstrates the productive potential of this cultivar in the soil and climatic conditions of Rio Grande do Sul.

Mazaro et al. (2013) working with the cultivars Camarosa, Camino Real and Albion in northern Paraná, better productivity results in Camarosa cultivar were observed with the worst being those for Albion.

The use of acclimatized cultivars for each region constitutes an important factor for the success in the production of strawberries (Pereira et al., 2013) and enables greater profitability for producers, and thus is important to search for better adapted cultivars for individual region.

\section{Materials and methods}

\section{Cultivation conditions and area preparation}

The research of the present study was conducted under low tunnels in the experimental field of the Federal University of Santa Maria, located in the city of Frederico Westphalen/RS, located geographically to $27^{\circ} 23^{\prime} 728^{\prime \prime} \mathrm{S}, 53^{\circ} 25^{\prime} 749^{\prime \prime} \mathrm{W}$ and $493 \mathrm{~m}$ of altitude. The climate is Cfa by Köppen climate classification.

The soil of the experimental area belongs to the mapping unit Passo Fundo, and is classified as a typical dystrophic Red Latosol with clayey texture, and is deep and well drained (Embrapa, 2006).

Soil preparations were done conventionally with plowing and harrowing before the planting of seedlings. Fertilization was applied according to the chemical analysis of soil and calculated and according to the crop requirements (Santos and Medeiros 2003). Cattle manure was incorporated by harrowing at a dose of $5.5 \mathrm{~kg} \mathrm{~m}^{-2} 45$ days before planting. During the planting, fertilizer at a dose of $55 \mathrm{~g} \mathrm{~m}^{-2}$ was used with the formula $10-20-10$.
The non-vernalized seedlings were planted on May 25th, 2015 , and vernalized seedlings on June 11th, 2015, with a spacing of $0.30 \times 0.30 \mathrm{~m}$, in plots containing a width of $1.2 \mathrm{~m}$ and a length of $16 \mathrm{~m}$, with four rows of plants on each plot, already containing mulching (black plastic film). Irrigation and fertigation were conducted via drip tape and cultural practices were maintained according to a cultivar's requirement. The low tunnels were installed on June 17th, 2015 , with low density polyethylene with a thickness of 100 $\mu \mathrm{m}$.

\section{Experimental design}

A randomized block factorial design $2 \times 2$ was used, with two strawberry cultivars of neutral and short day (Albion and Camarosa respectively) and two treatments (with and without vernalization), totaling four treatments distributed in four blocks each and the experimental unit consisting of eight plants/repetition.

Strawberry seedlings with bare roots from nursery located in the city of Agudo, RS were used. Part of the seedlings did not receive vernalization and were planted immediately after arrival in the experimental area, while the part received artificial vernalization before planting in a cold chamber for 200 hours at $4{ }^{\circ} \mathrm{C}$.

For the calculation of the average air temperature, data for the minimum and maximum air temperature inside the tunnels was collected with digital thermohygrograph; the following formula was used where $T$ represents the temperature: Tave $=\operatorname{Tmax}+\operatorname{Tmin} / 2$.

The daily thermal sum (STd) was calculated according to the following equation (Arnold, 1960): $S T d=($ Tave-Tb). 1 day $\left\{{ }^{\circ} \mathrm{C}\right.$ day $\}$.

The base temperature $(\mathrm{Tb})$ is defined as the sum of daily thermal units above a lower base temperature; below it the plant does not grow or its development is so slow that it can be neglected (Rosa et al., 2013), for strawberry it was used the $\mathrm{Tb}$ of $7{ }^{\circ} \mathrm{C}$ (Mendonça et al., 2012).

The thermal sum (Std) was calculated beginning at the transplanting of the seedlings, and the accumulated thermal sum (STa) was obtained which is the summation of the daily thermal sum: $S T a=\Sigma S t d\left\{{ }^{\circ} \mathrm{C} d a y\right\}$.

\section{Experiment evaluations}

A number of morphogenetic responses were evaluated during the crop cycle: phyllochron $\left({ }^{\circ} \mathrm{C}\right.$ day leaf $\left.^{-1}\right)$ for the number of commercial and non-commercial fruits, production of commercial and non-commercial fruits (g/plant), total titratable acidity (\% of citric acid), total soluble solids ( ${ }^{\circ}$ Brix) and ratio of total soluble solids titratable acidity.

For the variable of phyllochron, the number of leaves on the main crown was counted every three days beginning at the first emission of leaves until full bloom at which point the plant emitted the second floral raceme (Mendonça et al, 2012). For the counting, a leaf was considered to be a leaf when it was visible and the leaflets did not touch anymore. For the estimation of the phyllochron, a linear regression was performed between the number of crown leaves and the accumulated thermal sum. The phyllochron $\left({ }^{\circ} \mathrm{C}\right.$ day leaf -1$)$ was estimated as being the inverse of the angular coefficient of the linear regression (Mendonça et al, 2012).

Fruits were harvested twice per week at the stage of full maturity (90\% of ripe fruit) and then two variables were recorded: production of commercial and non-commercial fruit. Non-commercial fruits were considered to be ones which had become deformed or weighed less than $6 \mathrm{~g}$. 
Qualitative analyses of the fruits were performed throughout the cycle in order to eliminate specific characteristics of the harvest season. The variables of total titratable acidity and total soluble solids were analyzed in the laboratory, and made from eight harvested fruits in each plot. The determination of total acidity was performed by titration with a standardized solution of $\mathrm{NaOH} 0.1 \mathrm{~mol} \mathrm{~L}^{-1}$, and the determination of total soluble solids using a manual refractometer.

The results were submitted to analysis of variance, and the means were compared by Tukey test at 5\% of error probability by the statistical program Genes (Cruz, 2013).

\section{Conclusion}

Artificial vernalization of seedlings did not significantly effect phyllochron nor the quality of the produced fruits; significant effect were only seen for the factor of cultivar. The use of national vernalized seedlings resulted in an elevated production of fruit; the Camarosa cultivar was seen to be more productive than the Albion cultivar.

\section{Acknowledgments}

We thank to M. Sci. John Stolzle for English grammar review. We also would like to thank AJCS Editorial review board members for the valuable contribution given in this manuscript.

\section{References}

Akhato I, Recamales FA (2013) Influence of cultivar and culture system on nutritional and organoleptic quality of strawberry. J Sci Food Agr. (94):866-875.

Anuário Brasileiro da Fruticultura 2014 (2015) Santa Cruz do Sul: Editora Gazeta, Santa Cruz, 104 p.: il.

Antunes LEC, Peres NA (2013) Strawberry production in Brazil and South America. I. Journal of Fruit Sc. (13):1-2.

Arnold CY (1960) Maximum-Minimum temperature as a basis for computing heat units. A Soc Hort Sci. (76): 682-692.

Capocasa F, Scalzo J, Mezzetti B, Battino M (2008) Combining quality and antioxidant attributes in the strawberry: the role of genotype. Food Chem. (111):872-878.

Cocco C, Gonçalves MA, Ferreira LV, Vignolo GK, Carvalho SF, Antunes LEC(2016) Produção de cultivares de morangueiro de dias-curtos na região de Pelotas-RS. In: Encontro de Pós Graduação UFPel, 13, 2011, Pelotas. Anais... Pelotas, nov. 2011. Disponível em: http://www.ufpel.edu.br/enpos/2011/anais/ca.htm. Acssec em 03 mar 2016.

Cocco C, Andriolo J L, Cardoso FL, Erpen L, Schmitt OJ (2011) Crown size and transplant type on the strawberry yield. Sci. Agricola (68):489-493.

Costa RC, Calvete EO, Mendonca HFC, Decosta LA (2014) Phenology and leaf accumulation in vernalized and non-vernalized strawberry seedlings in neutral-days. Acta Sci Agron. (36):57-62.

Dias JPT, Duarte Filho J, Pádua JG, Carmo EL (2009) Desempenho produtivo da cultivar Palomar nas condições de Pouso Alegre-MG. Hort Bras.(27): S2318-S2322

Duarte Filho J, Cunha RJP, Alvarenga DA (1999) Aspectos do florescimento e técnicas empregadas objetivando a produção precoce em morangueiros. Informe Agropecuário (20):30-35 .

EMBRAPA - Empresa Brasileira de Pesquisa Agropecuária. Sistema Brasileiro de Classificação de Solos. 2. ed, Rio de Janeiro: Embrapa SPI, 2006. 412p.

Gunduz K, Ozdemir E (2014) The effects of genotype and growing conditions on antioxidant capacity, phenolic compounds, organic acid and individual sugars of strawberry. Food Chem. (155):298303.

Massa GD, Chase E, Santini JB, Mitchell CA (2015) Temperature affects long-term productivity and quality attributes of day-neutral strawberry for a space life-support system. Life Sci Space Res. (5): $39-46$.
Mazaro SM, Mangnabosco MC, Citadin I, Paulus D, Gouvêa A (2013) Produção e qualidade do morangueiro sob diferentes concentrações de calda bordaleza, sulfocálcica e biofertilizante super-magro. Semin: Cien Agrar. (34): 3285-3294.

Mendonca HFC, Calvete EO, Nienow AA, Costa RC, Zerbielli L, Bonafé M (2012) Phyllochron estimation in intercropped strawberry and monocrop systems in a protected environment. Rev Bras Fruticultura. (34):15-23.

Oliveira RP, Scivittaro WB, Rocha PSG, Severo J, Silva JA, Gularte VF (2009) 'Strawberry Festival': nova cultivar de morangueiro recomendada para o Rio Grande do Sul. Boletim de Pesquisa e Desenvolvimento 96, Pelotas: Embrapa Clima Temperado, 21p.

Yang D, Liang J, Xie H, Wei X (2016) Norsesquiterpenoids and triterpenoids from strawberry cv. Falandi. Food Chem. (203): $67-$ 72.

Pereira WR, Souza RJ, Yuri JE, Ferreira S (2013) Produtividade de cultivares de morangueiro, submetidas a diferentes épocas de plantio. Hortic Bras. (31): 500-503.

Radin B, Lisboa BB, Witter S, Barni V, Reisser Junior C, Matzenauer R, Fermino MH (2011) Desempenho de quatro cultivares de morangueiro em duas regiões ecoclimáticas do Rio Grande do Sul. Hortic Bras. (29):287-291.

Rosa HT, Streck NA, Walter LC, Andriolo JL, Silva MR (2013) Crescimento vegetativo e produtivo de duas cultivares de morango sob épocas de plantio em ambiente subtropical. Rev. Ciencia Agron. (44): 604-613.

Ruan J, Yoon C, Yeoung Y, Larson KD, Ponce L (2009) Efficacy of highland production of strawberry transplants. Afr J Biotechnol. (8): 1497-1501.

Samykannoa K, Panga E, Marriot PJ (2013) Genotypic and environmental effects on flavor attributes of 'Albion' and 'Juliette' strawberry fruits. Sci Hort. (164): 633-642.

Santos AM, Medeiros ARM. Morango: Produção. Frutas do Brasil. Embrapa Clima Temperado, 2003, 81p.

Serçe S, Hancock JF (2009) The temperature and photoperiod regulation of flowering and runnering in the strawberries, Fragaria chiloensis, $F$. virginiana and $F$. x ananassa. Sci Hort. (103): 167 177.

Sonsteby A, Opstad N, Heide OM (2013) Environmental manipulation for establishing high yield potential of strawberry forcing plants. Sci Hort. (157): 65-73.

Tanino KK, Wang R (2008) Modeling chilling requirement and diurnal temperature differences on flowering and yield performance in strawberry crown production. HortScience, (43): 2060-2065.

Tazzo IF, Fagherazzi AF, Lerin S, Kretzschmar AA, Rufato L (2015) Exigência térmica de duas seleções e quatro cultivares de morangueiro cultivado no planalto catarinense. Rev Bras Fruticultura. (37): 550-558

Wrege MS, Reisser Júnior C, Antunes LEC, Oliveira RPD, Herter FG, Steinmetz S, Garrastuzu MC, Matzenauer R, Santos AMD (2007). Zoneamento agroclimático para produção de mudas de morangueiro no Rio Grande do Sul. Documentos, 187. Pelotas: Embrapa Clima Temperado, 27p.

Verdial MF, Tessarioli Neto J, Minami K, Scarpare Filho JA, Christoffoleti PJ, Scarpare FV, Kluge RA (2007) Vernalização em cinco cultivares de morangueiro; Vernalization on five cultivars of strawberry. Ciên Rural. (37): 976-981.

Verheul MJ, Sonsteby A, Grimstad ASO (2007) Influences of day and night temperatures on flowering of Fragaria $\times$ ananassa Duch., cvs Korona and Elsanta. Sci Hort. (112): 200-2006. 